\title{
Germanica
}

\section{Impossibles retours}

Geneviève Roussel

\section{OpenEdition}

Journals

Édition électronique

URL : http://journals.openedition.org/germanica/5275

DOI : 10.4000/germanica. 5275

ISSN : 2107-0784

\section{Éditeur}

Université de Lille

\section{Édition imprimée}

Date de publication : 30 juin 1987

Pagination : 5-6

ISSN : 0984-2632

\section{Référence électronique}

Geneviève Roussel, «Impossibles retours », Germanica [En ligne], 1 | 1987, mis en ligne le 25

septembre 2018, consulté le 06 octobre 2020. URL : http://journals.openedition.org/germanica/5275 ; DOl : https://doi.org/10.4000/germanica.5275

Ce document a été généré automatiquement le 6 octobre 2020.

(c) Tous droits réservés 


\title{
Impossibles retours
}

\author{
Geneviève Roussel
}

1 La silhouette du voyageur qui rentre - exilé, aventurier, fils prodigue, Orphée ou Ulysse -hante nos imaginaires, surgit au fil de nos lectures... Ce mythe du retour, l'Histoire l'a, au vingtième siècle, revisité comme pour un plus funèbre inventaire.

2 Les études ici réunies voudraient sensibiliser à certaines inflexions du thème tout au long du siècle. Les œuvres considérées témoignent d'expériences vécues, aiguisées par la lucidité, épurées par l'art et le temps. Ou bien, si les implications personnelles sont plus discrètes ou recomposées, abordent le thème millénaire du retour selon la tradition, mais avec un frémissement amer ou nostalgique. Elles avouent - semble-t-il qu'il n'y a plus guère de retrouvailles harmonieuses, tant sont aujourd'hui hésitante l'identité du voyageur, hétéroclites son souvenir et son désir, chaotiques les images, vécues ou rêvées, de maison, de foyer, de patrie.

Comme résignés aux retours viciés, voyageurs en partance et voyageurs revenus se croisent - voyageurs en souffrance - dans la salle des pas perdus de notre siècle. 